\title{
Stimuli that induce production of Candida albicans extracellular aspartyl proteinase
}

\author{
Claude G. Lerner and Robert C. Goldman*
}

Abbott Laboratories, Anti-infective Research Division of Pharmaceutical Discovery, D47M-AP9A, 1 Abbott Park Road, Abbott Park, IL 60064-3500, USA

(Received 16 November 1992; revised 19 February 1993; accepted 4 March 1993)

\begin{abstract}
Several species of the opportunistic fungal pathogen Candida produce an extracellular aspartyl proteinase that may assist the organism to invade and colonize host tissues, evade the host immune response and assimilate nitrogen from proteinaceous sources. Although addition of exogenous proteins, such as bovine serum albumin (BSA), to cultures of $\boldsymbol{C}$. albicans is known to elicit proteinase production, the precise molecular mechanisms controlling regulation of proteinase induction are unknown. We have examined the ability of a variety of macromolecules to induce proteinase production using a chemically-defined nitrogen-limited growth medium and a rapid, sensitive microtitre fluorescent assay for proteinase activity in culture supernatants. BSA and the extracellular matrix protein collagen induced proteinase production. Homopolymers of both poly-L- and poly-Dglutamate also induced proteinase activity, whereas polyglycine, heparin sulphate and dextran sulphate did not. Thus, molecular recognition of proteinase-inducing stimuli is not highly stereospecific, but apparently requires both main- and side-chain interactions. Peptides 8 or more residues in length generally induced proteinase production while most shorter peptides did not. These data reveal that internalization of small peptides with less than 7 residues by peptide transport was not the inducing signal for proteinase production, since Candida dipeptide and oligopeptide permeases do not efficiently transport peptides of more than 6-7 residues. In addition a tight-binding synthetic inhibitor of Candida proteinase $\left(K_{\mathrm{i}}=0.17 \mathrm{nM}\right)$ prevented growth of $C$. albicans on BSA as a sole nitrogen source by blocking protein degradation. Immunodetection of proteinase in these culture supernatants suggests that fully intact proteins, in addition to peptide fragments of sufficient size, are capable of inducing proteinase production. A model involving stimulation of a plasma membrane signal transduction event by extracellular protein and/or polypeptide ligands of more than seven residues is compatible with these data.
\end{abstract}

\section{Introduction}

The clinically important opportunistic fungal pathogens of the genus Candida produce an extracellular acid (aspartyl) proteinase in vivo during infection (MacDonald \& Odds, 1980; Ruchel et al., 1983, 1991; De Bernardis et al., 1990), as well as in vitro when cultured in the presence of exogenous protein as a nitrogen source (Staib, 1965; Remold et al., 1968; Ruchel, 1981; Hattori et al., 1984; Kaminishi et al., 1986; Ross et al., 1990; Ray \& Payne 1990; Banerjee et al., 1991). While some debate exists as to the importance

${ }^{*}$ Author for correspondence. Tel. (708) 937 4477; fax (708) 938 6603; e-mail: goldmanr@randb.abbott.com.

Abbreviation: EDANS, [5-(2-aminoethyl)-amino]-naphthalene-1sulphonic acid. of the proteinase in virulence, proteinase production is considered to enhance the organism's ability to colonize and penetrate host tissues, and to evade the host immune system (Ruchel et al., 1983; MacDonald, 1984; Odds, 1985; Ruchel; 1983, 1986; Douglas, 1988; Borg \& Ruchel, 1990; Cutler, 1991). Correlation between virulence and levels of proteinase production in both clinical isolates of $C$. albicans (Ghannoum \& Abu Elteen, 1986; De Bernardis et al., 1990) and laboratory isolates with altered proteinase levels (MacDonald \& Odds, 1983; Kwon-Chung et al., 1985; Kondoh et al., 1987; Ross et al., 1990) generally supports the notion of its role in virulence. The proteinase hydrolyses a variety of extracellular substrates, including albumin (Remold et al., 1968), immunoglobulins, coagulation factor $\mathrm{X}$, angiotensinogen analogues, and haemoglobin (Ruchel, 1986), keratin (Hattori et al., 1984) and collagen (Kaminishi et al., 1986, 1988). 
Although proteinase production is induced by a variety of protein substrates, the precise molecular mechanisms controlling regulation of proteinase induction are unknown. In addition to bovine serum albumin (BSA) (Remold et al., 1968), proteinase production is induced in vitro by haemoglobin (Ruchel, 1981), histones and ovalbumin (Banerjee et al., 1991), keratin (Hattori et al., 1984), collagen (Kaminishi et al., 1986, 1988) and human serum (Capobianco et al., 1992). Complex mixtures of peptides (peptone and tryptone) can also stimulate proteinase production in vitro (Banerjee et al., 1991). Although induction of proteinase synthesis is tightly coupled to secretion and proteinase does not accumulate in cells (Ross et al., 1990; Banerjee et al., 1991), intracellular precursors do exist (Homma et al., 1992). Thus exogenous protein induces the synthesis and secretion of newly synthesized proteinase rather than stimulating exocytotic secretory vesicles containing stored proteinase. Mechanisms by which induction of proteinase synthesis and secretion could occur include: (i) transmembrane signal transduction in which cell surface receptors bind proteinaceous ligand molecules, thus signalling induction of proteinase synthesis; (ii) peptides released from protein in the medium due to the basal level of proteinase production are transported via Candida peptide permeases (Payne \& Shallow, 1985; McCarthy et al., 1985; Milewski et al., 1988; Naider \& Becker, 1988; Payne et al., 1991; Shallow et al., 1991), thus allowing accumulated intracellular peptides to trigger an increase in proteinase synthesis and secretion; and (iii) internalization of protein and/or peptides by fluid phase (Basrai et al., 1990), or receptor-mediated endocytosis, with subsequent signalling of proteinase induction by engulfed material.

We used several improvements over existing methodologies to elucidate further the molecular mechanism of induction of proteinase synthesis and secretion, and to determine the general characteristics of compounds which induce proteinase production. An extremely sensitive, rapid fluorescent microtitre assay for Candida aspartyl proteinase activity (Capobianco et al., 1992), previously developed to discover inhibitors of enzyme activity, was used to monitor extracellular proteinase production. This assay detected extracellular proteinase activity induced by BSA or human serum in all strains of $C$. albicans, C. tropicalis, C. stellatoidea, $C$. $k e f y r, C$. lusitaniae and C. krusei tested (Capobianco et al., 1992). The level of proteinase followed the order $C$. albicans/stellatoidea $>C$. tropicalis $>C$. kefyr $>C$. lusitaniae $>C$. krusei. In addition, a completely defined medium was developed which allowed precise examination of the chemical nature of the inducing stimulus, including factors such as peptide size and amino acid side-chain stereochemistry. Finally, the availability of a fast-tight binding inhibitor (Capobianco et al., 1992) of the proteinase allowed examination of whether fully intact proteins, in the absence of peptides, could induce proteinase production.

\section{Methods}

Materials. The fluorogenic peptide substrate, 4-(4-dimethylaminophenylazo)benzoyl- $\gamma$-aminobutyryl)-Ile-His-Pro-Phe-His-Leu-Val-IleHis-Thr-[5-(2-aminoethyl)-amino]naphthalene-1-sulphonic acid, was synthesized at Abbott Laboratories as previously described for other substrates of this type (Capobianco et al., 1992). This substrate is commercially available from Molecular Probes Inc. (Eugene, OR, USA; catalogue no. R-2931). The proteinase inhibitor, (2S)-2-\{(3R)-3benzyl-4- $N$-(4-methylpiperazin-1-yl-carbonyl)-2-keto-piperazin-1-yl $\}$ hexanoic acid amide hydrochloride (A-70450), was prepared at Abbott Laboratories according to the methods described in US Patent 5120718. Dextran, bovine serum albumin and collagen were obtained from Sigma. Peptides and protein homopolymers including Lys-Val, Arg-Gly, $\beta$-lipotropin fragment (KKDSGPY), angiotensin I (DRVYIHPFHL), angiotensin II (DRVYIHPF), bradykinin (RPPGFSPFR), bradykinin fragment 1-7 (RPPGFSP), laminin fragment 929-933 (YIGSR), neurotensin fragment 1-8 (ELYENKPR), neurotensin fragment 1-11 (ELYENKPRRPY), neurotensin (ELYENKPRRPYIL), polyglycine, poly-D-glutamate, poly-Lglutamate, poly-D-lysine and poly-L-lysine were obtained from Sigma. Angiotensin III (RVYIHPF), cholecystokinin heptapeptide 27-33 (YMGWMDF), cholecystokinin hexapeptide 28-33 (MGWMDF), [Met ${ }^{5}$-enkephalin (YGGFM), and [Met ${ }^{5}$-enkephalin-Lys-Gly-Leu (YGGFMRGL) were obtained from Clontech Laboratories. Heparin sulphate was obtained from ICN Biochemicals and dextran sulphate from Pharmacia.

Organism and growth conditions. C. albicans strains ATCC 10261 and 10231 (originally obtained from the American Type Culture Collection, Rockville, MD, USA) were from our culture collection and were grown at $37^{\circ} \mathrm{C}$. The chemically defined basic medium consisted of yeast nitrogen base (Difco), lacking amino acids and $\left(\mathrm{NH}_{4}\right)_{2} \mathrm{SO}_{4}$, but supplemented with $2.0 \%$ (w/v) glucose (YNB/glucose) and other nutrients as indicated. Complete amino acid supplementation (Ausubel et al., 1990) consisted of $\left(\mu \mathrm{g} \mathrm{m}^{-1}\right.$ final concn): L-arginine (20), Laspartic acid (100), L-glutamic acid (100), L-histidine (20), L-leucine (60), L-lysine (30), L-methionine (20), L-phenylalanine (50), L-serine (375), L-threonine (200), L-tryptophan (40), L-tyrosine (30) and L-valine (150). Additional supplementation with adenine to $40 \mu \mathrm{g} \mathrm{ml}^{-1}$ and uracil $\left(20 \mu \mathrm{g} \mathrm{ml}^{-1}\right)$ was included with the amino acids. Nutritional supplements were obtained from Sigma. All liquid media were filtersterilized. Media for plates contained YNB/glucose, complete amino acid supplementation, adenine, uracil, $\left(\mathrm{NH}_{4}\right)_{2} \mathrm{SO}_{4}\left(5 \mathrm{mg} \mathrm{ml}^{-1}\right)$ and $1.4 \%(\mathrm{w} / \mathrm{v})$ agar. Liquid cultures of nitrogen-limited C. albicans were prepared by inoculating single colonies from plates into $\mathrm{YNB}$ /glucose medium containing $\left(\mathrm{NH}_{4}\right)_{2} \mathrm{SO}_{4}\left(0.2 \mathrm{mg} \mathrm{ml}^{-1}\right)$, but lacking amino acids. After overnight incubation, cultures were diluted (about 1:50) to an $\mathrm{OD}_{420}$ of 0.15 with fresh nitrogen-limited medium (NL-YNB/glucose) which contained $\mathrm{YNB} /$ glucose and $\left(\mathrm{NH}_{4}\right)_{2} \mathrm{SO}_{4}\left(0.025 \mathrm{mg} \mathrm{ml}^{-1}\right)$, with or without additional nitrogen sources as indicated. Standard induction of proteinase production was achieved by addition of filter-sterilized BSA. Other putative inducers were prepared as $20-40 \%(\mathrm{w} / \mathrm{v})$ stocks in dimethylsulphoxide (DMSO), and were added to media at final concentrations of $0.2-0.4 \mathrm{mg} \mathrm{ml}^{-1}$. Addition of DMSO up to $10 \%$ $(\mathrm{v} / \mathrm{v})$ did not interfere with growth or proteinase induction by BSA.

Proteinase assay. Secreted aspartyl proteinase production in cultures of $C$. albicans was assayed by the fluorescent method of Capobianco et 
al. (1992) in which proteolysis is detected by cleavage of a peptide fluorogenic substrate (see Materials), yielding an increase in relative fluorescence intensity. The primary cleavage site is between His and Thr (Capobianco et al., 1992). Cell-free supernatants were prepared by centrifugation of culture samples for $5 \mathrm{~min}$ at $15000 \mathrm{~g}$ in a TOMY microcentrifuge. Aliquots were assayed for proteinase activity in microfluor plates (Dynatech) using the fluorescent assay. Reaction mixtures contained $16 \mu \mathrm{M}$-fluorogenic substrate in $50 \mathrm{~mm}$-sodium citrate buffer $\mathrm{pH} 4.5$ plus $20 \mu \mathrm{l}$ culture supernatant in a final volume of $200 \mu \mathrm{l}$. The reaction was initiated by addition of substrate (in $100 \mu \mathrm{l}$ citrate buffer, $\mathrm{pH} 4.5$ ) to culture supernatants in $100 \mu l 8 \mathrm{~mm}$-sodium citrate buffer $\mathrm{pH} 6.8$. The increase in relative fluorescence intensity (RFI) was measured over time at $22^{\circ} \mathrm{C}$ in a luminescence spectrophotometer (Perkin-Elmer LS-50) equipped with a 96-well microplate reader. The excitation wavelength was $340 \mathrm{~nm}$ and the emission was monitored at $490 \mathrm{~nm}$ ( $430 \mathrm{~nm}$ filter employed). Reaction rates were determined by linear regression analysis of plots of the increase in relative fluorescence versus time. Analysis was performed on at least four data points defining line fits with $r^{2}$ values of greater than 0.98 . An estimate of the mass concentration of proteinase was calculated as the product of the rate of change in fluorescence units $\min ^{-1}$ multiplied by the constant $14.42 \mu \mathrm{g} \mathrm{ml}^{-1} \Delta \mathrm{RFI} \mathrm{min}^{-1}$. This constant was calculated from the reaction volumes, specific activity of highly purified proteinase $\left(15300 \mathrm{nmol} \mathrm{h}^{-1} \mathrm{mg}^{-1}\right)$ and the RFI of pure EDANS (2.72 RFI at $1 \mu \mathrm{M})$, which was corrected for the inner filter effect as described (Capobianco et al., 1992). The RFI was converted to concentration of product released as described previously (Capobianco et al., 1992). Several methods are used in the literature to estimate secreted protease activity, making comparisons difficult. We present the following conversion factors: 1.0 haemoglobin unit $=0.88$ BSA units $=0.90 \mathrm{nmol}$ Thr-EDANS released from the fluorogenic substrate, where the specific activity is $15300 \mathrm{nmol}$ Thr-EDANS released $\mathrm{h}^{-1} \mathrm{mg}^{-1}$ for protease purified from C. albicans strain ATCC 10231. Although the specific activity of purified protease from $C$. albicans strain ATCC 10261 used in the present study was not determined, data were converted to allow an estimate of mass based on the specific activity of protease from strain 10231 .

SDS-PAGE, electrotransfer, and immunoblotting. Samples of culture supernatants were examined for the presence of proteinase by immunodetection of antigen transferred from $12 \%(\mathrm{w} / \mathrm{v})$ SDS-PAGE gels to nitrocellulose by semi-dry electroblotting. Proteins were concentrated from the cell-free culture supernatant by acetone precipitation. Ice-cold acetone $(0.9 \mathrm{ml})$ was added to $0.1 \mathrm{ml}$ chilled culture supernatant, and the sample was mixed and kept on ice for $45 \mathrm{~min}$. The precipitate was collected by centrifugation for $15 \mathrm{~min}$ in a microcentrifuge at $4{ }^{\circ} \mathrm{C}$. The supernatant was carefully decanted and the pellet gently dried under a stream of air. The pellet was resuspended in $16.5 \mu \mathrm{l} \mathrm{H} \mathrm{H}_{2} \mathrm{O}$. After addition of an equal volume of $2 \times$ sample buffer (Ross et al., 1990) the sample was heated at $100^{\circ} \mathrm{C}$ for $10 \mathrm{~min}$ and $12.5 \mu \mathrm{l}$ applied to a $12 \%$ gel (Mini-Protean II, Bio-Rad). The samples were electrophoresed at $80 \mathrm{~V}$ for $2 \mathrm{~h}$ in $49 \mathrm{~mm}$-Tris, $384 \mathrm{~mm}$-glycine, $0.1 \%(\mathrm{w} / \mathrm{v})$ SDS. Following electrophoresis the gel was soaked in semidry transfer buffer (48 mM-Tris base, $38 \mathrm{~mm}$-glycine, 0.037\% SDS, $20 \%, \mathrm{v} / \mathrm{v}$, methanol). After $15 \mathrm{~min}$ a piece of wet nitrocellulose was laid on top of the gel and the two layers were assembled into a sandwich between six sheets of semi-dry transfer buffer soaked Whatmann 3MM chromatography paper. The gel was placed in a semi-dry transfer apparatus (Gelman) and the proteins were transferred to the nitrocellulose by electrophoresis at $0.8 \mathrm{~mA} \mathrm{~cm}^{-2}$ for $1.5 \mathrm{~h}$. Following transfer the filter was incubated in $2 \%$ BSA, TBST ( $20 \mathrm{~mm}$-Tris, $500 \mathrm{~mm}-\mathrm{NaCl}$, $0.05 \%$ Tween-20) overnight. The next day the filter was probed for $45 \mathrm{~min}$ with a $1: 3000$ dilution (in TBST) of rabbit anti-proteinase antiserum raised against purified secreted aspartyl proteinase from strain ATCC 10261 (kindly provided by P. A. Sullivan, University of Otago,
New Zealand). Following $3 \times 10$ min washes with TBST the blot was incubated with a 1:3000 dilution (in TBST) of secondary alkalinephosphatase-conjugated goat anti-rabbit IgG. After 45 min incubation the filter was washed as above and the blot developed with alkaline phosphatase colour development reagents (5-bromo-4-chloro-indolyl phosphate, nitrotetrazolium blue; Bio-Rad).

\section{Results and Discussion}

\section{Media conditions for testing $C$. albicans proteinase induction}

Limiting the supply of inorganic nitrogen is important for maximal induction of proteinase production (Ross et al., 1990; Banerjee et al., 1991). To evaluate the ability of various compounds to induce proteinase production, we developed appropriate media conditions to obtain nitrogen-limited cultures. This was achieved by preparing nitrogen-starved overnight cultures which were subcultured in chemically defined medium containing $\left(\mathrm{NH}_{4}\right)_{2} \mathrm{SO}_{4}$ as the sole limiting nitrogen source. We first determined the level of $\left(\mathrm{NH}_{4}\right)_{2} \mathrm{SO}_{4}$ required in overnight cultures to effectively yield a nitrogen-starved culture in the morning. Nitrogen starvation was not observed when overnight cultures of C. albicans ATCC 10261, grown on $\mathrm{YNB}$ /glucose containing the usual level of $\left(\mathrm{NH}_{4}\right)_{2} \mathrm{SO}_{4}$ $\left(5 \mathrm{mg} \mathrm{ml}^{-1}\right)$, were used to inoculate fresh $\mathrm{YNB} /$ glucose medium completely lacking a source of nitrogen, i.e. such cells exhibited transient growth. Nitrogen starvation was obtained when overnight cultures were grown in $\mathrm{YNB} /$ glucose with $0.2 \mathrm{mg}\left(\mathrm{NH}_{4}\right)_{2} \mathrm{SO}_{4} \mathrm{ml}^{-1}$, since these cultures did not grow when transferred into fresh YNB/glucose lacking a nitrogen source. We next determined the amount of growth obtained when such nitrogen-starved cultures were transferred into $\mathrm{YNB}$ /glucose containing various amounts of $\left(\mathrm{NH}_{4}\right)_{2} \mathrm{SO}_{4}$. Starved cultures grew to levels dependent on the amount of $\left(\mathrm{NH}_{4}\right)_{2} \mathrm{SO}_{4}$ present in the $\mathrm{YNB} /$ glucose into which they were subcultured. Transfer of overnight cultures grown at $37^{\circ} \mathrm{C}$ in $\mathrm{YNB} /$ glucose with $0.2 \mathrm{mg}$ $\left(\mathrm{NH}_{4}\right)_{2} \mathrm{SO}_{4} \mathrm{ml}^{-1}$ into $\mathrm{YNB} /$ glucose medium containing $0.025 \mathrm{mg}\left(\mathrm{NH}_{4}\right)_{2} \mathrm{SO}_{4} \mathrm{ml}^{-1}$ yielded apparent nitrogen exhaustion after $7 \mathrm{~h}$ growth, reaching a maximal $\mathrm{OD}_{420}$ of 0.75 . These culture conditions were used to test induction of proteinase production since it appeared obvious that proteinase synthesis would initially require a non-protein source of nitrogen to support cellular protein synthesis until such time that a proteinaceous inducer could provide an adequate nitrogen source for further growth.

Growth on BSA as a sole nitrogen source requires proteinase production. We evaluated the amount of cell growth in NL-YNB/glucose media containing various concentrations of BSA, in order to estimate the minimal concentration of putative inducer required for expression 


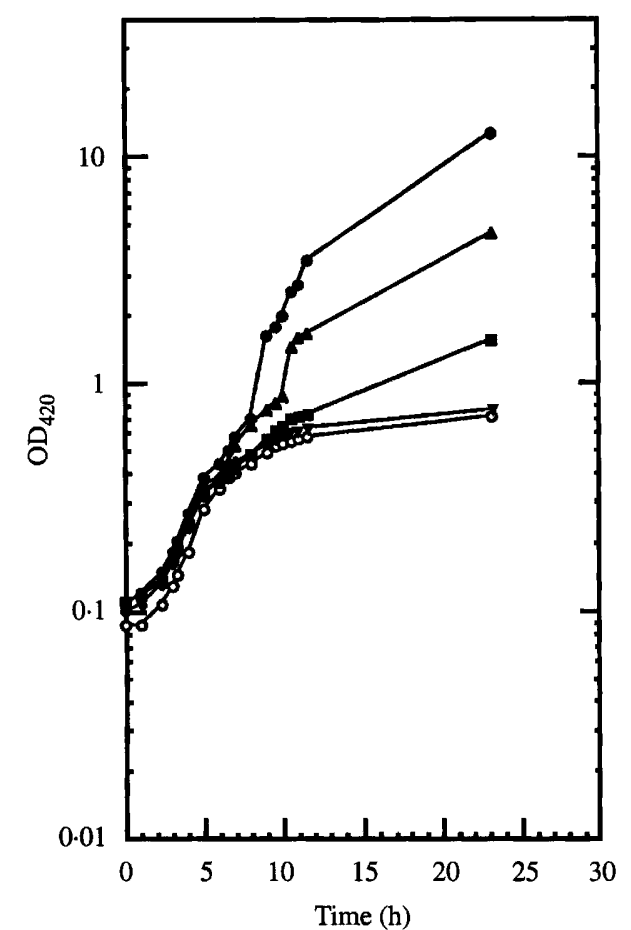

Fig. 1. Growth yield in various concentrations of BSA. C. albicans strain ATCC 10261 was grown overnight in NL-YNB/glucose to induce nitrogen starvation. Cells were subcultured into $\mathrm{YNB} /$ glucose containing $0.025 \mathrm{mg}\left(\mathrm{NH}_{4}\right)_{2} \mathrm{SO}_{4} \mathrm{ml}^{-1}$, and various amounts of BSA $\left(\mathrm{mg} \mathrm{ml}^{-1}\right):-, 2.0 ; \boldsymbol{\Delta}, 0.2 ; \boldsymbol{\square}, 0.02 ; \boldsymbol{\nabla}, 0.002 ; \mathrm{O}$, none. Growth was monitored at $420 \mathrm{~nm}$.

of significant levels of proteinase (Fig. 1). Full growth was supported by $2.0 \mathrm{mg} \mathrm{BSA} \mathrm{m}^{-1}$, while little or no growth occurred with $0.002 \mathrm{mg} \mathrm{ml}^{-1}$. Growth yield was 15 and $50 \%$ of maximum at 0.02 and $0.2 \mathrm{mg} \mathrm{BSA} \mathrm{ml}^{-1}$, respectively. Due to limited supplies of certain putative inducers, a concentration of $0.2 \mathrm{mg} \mathrm{m}^{-1}$ was tested for the ability to induce proteinase production. The rapid fluorescent assay was used to monitor the kinetics of proteinase produced during growth in the presence of BSA (Fig. 2). Proteinase activity was first detected in cultures at early-exponential phase, i.e. at $\mathrm{OD}_{420} 0 \cdot 8$, which coincides with the $\mathrm{OD}_{420}$ at which cultures lacking BSA exhibit a shift in growth rate due to nitrogen limitation (Fig. 1). Maximal proteinase production (Table 1) and final culture turbidity (Fig. 1) increased with increasing amount of BSA. Furthermore, the level of proteinase produced per $\mathrm{OD}_{420}$ unit was relatively constant (within twofold) and independent of BSA concentration, indicating that induced cells produce a constant amount of proteinase. Thus, the maximal amount of proteinase produced is dependent upon the amount of total cell growth rather than on an increase in the amount of proteinase each cell is producing at higher BSA concentrations. A $2 \mathrm{~h}$ delay in addition of BSA did not affect the timing or maximal level of proteinase production. This further supports the idea that induction of proteinase production is coupled to the onset of nitrogen limitation.

While the nitrogen-limiting NL-YNB/glucose medium was suitable for observing proteinase induction with good nitrogen sources such as BSA, it became apparent that proteinase production might not be observed with putative inducers that were poor nitrogen sources. For example, when collagen was added to the medium as sole nitrogen source, there was little cell growth and only low levels of proteinase activity were detected (data not shown). Since continued cell growth is required for detecting high levels of proteinase production, additional nitrogen supplements were evaluated to find appropriate culture conditions that would allow clear detection of proteinase induction by compounds that were poor nitrogen sources.

Excess $\left(\mathrm{NH}_{4}\right)_{2} \mathrm{SO}_{4}$ inhibits induction by proteinase by BSA (Crandall \& Edwards, 1987; Ross et al., 1990; Banerjee et al., 1991); thus we examined the effect of $\left(\mathrm{NH}_{4}\right)_{2} \mathrm{SO}_{4}$ and supplementation with amino acids on repression of BSA induction in order to determine the appropriate type of additional nitrogen supplementation (Table 1). Levels of proteinase activity detected in cultures containing $2 \mathrm{mg} \mathrm{BSA} \mathrm{ml}^{-1}$ were inversely related to the amount of $\left(\mathrm{NH}_{4}\right)_{2} \mathrm{SO}_{4}$ present. Proteinase activity was still detected in cultures supplemented with $5 \mathrm{mg}$ $\left(\mathrm{NH}_{4}\right)_{2} \mathrm{SO}_{4} \mathrm{ml}^{-1}$, while no proteinase activity was detected $\left(<0.0014 \mu \mathrm{g} \mathrm{ml}^{-1}\right)$ in the presence of $50 \mathrm{mg}$ $\left(\mathrm{NH}_{4}\right)_{2} \mathrm{SO}_{4} \mathrm{ml}^{-1}$ ( $<0.03 \%$ of the maximal control proteinase level). The culture containing $5 \mathrm{mg}$ $\left(\mathrm{NH}_{4}\right)_{2} \mathrm{SO}_{4} \mathrm{ml}^{-1}$ had not exhausted the supply of $\left(\mathrm{NH}_{4}\right)_{2} \mathrm{SO}_{4}$, because (i) the spent, filter-sterilized medium of a test culture grown in $\mathrm{YNB} /$ glucose plus $5 \mathrm{mg}$ $\left(\mathrm{NH}_{4}\right)_{2} \mathrm{SO}_{4} \mathrm{ml}^{-1}$ still supported full growth when reinoculated, and (ii) it only requires $0.5-1 \mathrm{mg}$ $\left(\mathrm{NH}_{4}\right)_{2} \mathrm{SO}_{4} \mathrm{ml}^{-1}$ to support maximum growth yields. These data indicate that induction of proteinase occurred while $\left(\mathrm{NH}_{4}\right)_{2} \mathrm{SO}_{4}$ was still present. Addition of a mixture of amino acids to media containing $\mathrm{BSA}$ and limiting ( $\left.0.025 \mathrm{mg} \mathrm{ml}^{-1}\right)$ or excess $\left(5.0 \mathrm{mg} \mathrm{ml}^{-1}\right)\left(\mathrm{NH}_{4}\right)_{2} \mathrm{SO}_{4}$ caused a slight reduction (about $30 \%$ ) in the amount of proteinase produced. Medium containing the amino acid mixture as the sole nitrogen source supported growth of the culture to high turbidity, indicating that these supplements provided an adequate nitrogen supply for growth. NL-YNB/glucose containing the amino acid mixture and limiting $\left(0.025 \mathrm{mg} \mathrm{ml}^{-1}\right)\left(\mathrm{NH}_{4}\right)_{2} \mathrm{SO}_{4}$ was therefore used to test proteinase induction by compounds which might not support further growth following exhaustion of limiting $\left(\mathrm{NH}_{4}\right)_{2} \mathrm{SO}_{4}$. Putative inducers were added to a final concentration of $0 \cdot 2-0.4 \mathrm{mg} \mathrm{ml}^{-1}$, which was adequate for induction of proteinase by BSA. 


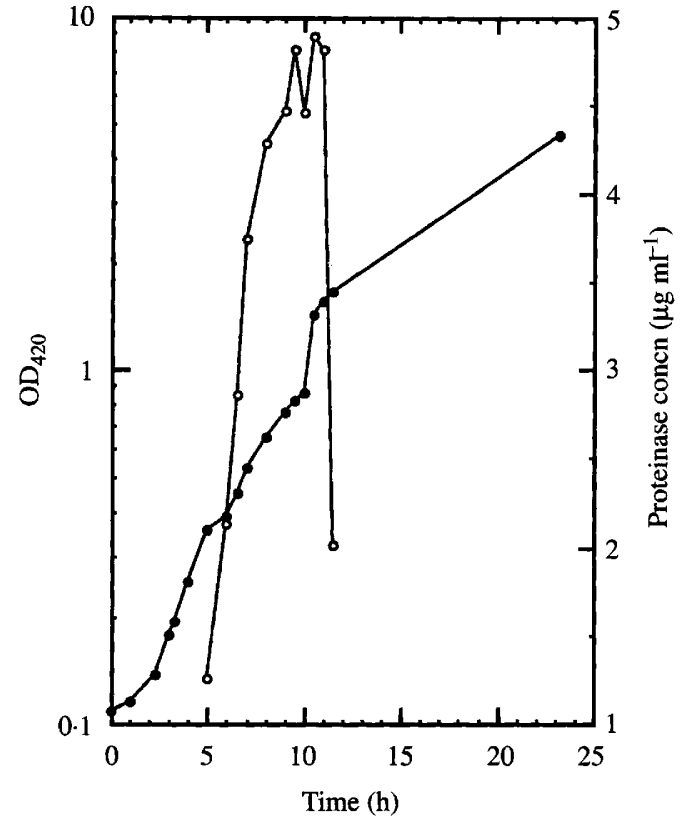

Fig. 2. Kinetics of proteinase production during growth of C. albicans strain ATCC 10261 with BSA as the sole nitrogen source. Nitrogenstarved cells were inoculated into $\mathrm{YNB} /$ glucose containing $0.025 \mathrm{mg}$ $\left(\mathrm{NH}_{4}\right)_{2} \mathrm{SO}_{4} \mathrm{ml}^{-1}$ and $0.2 \mathrm{mg} \mathrm{BSA} \mathrm{ml}{ }^{-1}$. Culture supernatants were collected and assayed for secreted proteinase using the fluorogenic substrate. The estimate of proteinase in the culture medium was calculated as given in Methods $\left[O\right.$, proteinase $\left.\left(\mu \mathrm{g} \mathrm{ml}^{-1}\right) ; 0, \mathrm{OD}_{420}\right]$.

\section{Table 1. Effect of nitrogen supplements on induction of} C. albicans aspartyl proteinase

Cells were grown in YNB/glucose with nitrogen supplements as indicated. Proteinase activity was monitored in culture supernatants during growth, and peak activities were detected using the fluorogenic peptide substrate.

\begin{tabular}{|c|c|c|c|c|}
\hline \multicolumn{3}{|c|}{ Nitrogen supplements } & \multirow{2}{*}{\multicolumn{2}{|c|}{ Proteinase production $\dagger$}} \\
\hline BSA & $(\mathrm{NH}) \mathrm{SO}$ & Amino acid & & \\
\hline$\left(\mathrm{mg} \mathrm{ml}^{-1}\right)$ & $\left(\mathrm{mg} \mathrm{ml}^{-1}\right)$ & mixture* & $\mu \mathrm{g} \mathrm{ml}^{-1}$ & $\%$ of control \\
\hline $2 \cdot 0$ & $0 \cdot 025$ & - & $5 \cdot 33$ & 100 \\
\hline $2 \cdot 0$ & 0.025 & + & $3 \cdot 61$ & 67 \\
\hline $2 \cdot 0$ & 0.2 & - & 1.87 & 35 \\
\hline $2 \cdot 0$ & 5 & - & 0.88 & 16 \\
\hline $2 \cdot 0$ & 5 & + & 0.58 & 11 \\
\hline $2 \cdot 0$ & 50 & - & ND & ND \\
\hline 0.2 & 0.025 & - & $4 \cdot 76$ & 89 \\
\hline 0.02 & 0.025 & - & $2 \cdot 3$ & 43 \\
\hline 0.002 & 0.025 & - & 0 & 0 \\
\hline
\end{tabular}

$*+$, Cultures were supplemented with a mixture of 13 amino acids $\dagger \mathrm{ND}$, Proteinase activity below the limit of detection ( $<0.0014 \mu \mathrm{g} \mathrm{ml}^{-1} ;<0.03 \%$ of control).

Similar to repression of expression of yeast peptide permeases (Island et al., 1987; Payne et al., 1991), amino acids seemed to repress proteinase production less than
Table 2. Induction of $C$. albicans aspartyl proteinase by polymers

Cells were grown in NL-YNB/glucose and amino acid supplements in the presence of polymer $\left(0.4 \mathrm{mg} \mathrm{m}^{-1}\right)$. Proteinase activity was monitored in culture supernatants during growth, and peak activities were detected using the fluorogenic peptide substrate.

\begin{tabular}{lrc}
\hline \hline Polymer & $M_{\mathrm{r}}$ & $\begin{array}{c}\text { Proteinase production } \\
\left(\mu \mathrm{g} \mathrm{ml}^{-1}\right)^{*}\end{array}$ \\
\hline Polyglycine & 5000 & ND \\
Poly-L-glutamate & 8400 & $1 \cdot 64$ \\
Poly-D-glutamate & 12000 & $1 \cdot 17$ \\
Poly-L-lysine & 4900 & $0 \cdot 36$ \\
Poly-D-lysine $\dagger$ & 11000 & ND \\
Heparin sulphate & 14000 & ND \\
Dextran sulphate & 500000 & ND \\
Dextran & 500000 & ND \\
\hline
\end{tabular}

${ }^{*}$ ND, Proteinase activity below the limit of detection ( $<0.0014 \mu \mathrm{g} \mathrm{ml}^{-1} ;<0.03 \%$ of control).

$\uparrow$ Poly-D-lysine was toxic and inhibited fungal growth.

$\left(\mathrm{NH}_{4}\right)_{2} \mathrm{SO}_{4}$. This seems a reasonable cellular response, since the presence of amino acids would be a likely indicator that proteins were also present, and cells would thus benefit from the partial induction of proteinase synthesis.

\section{Survey of proteinase induction by proteins and large} polymers

The amino-acid-supplemented NL-YNB/glucose medium was used to monitor induction of proteinase by various compounds, some of which might not be good nitrogen sources. The charge and stereospecificity requirements of the sensory apparatus involved in induction of proteinase production were examined using $\mathrm{D}$ and $\mathrm{L}$ isomer forms of peptide homopolymers (Table 2 ). Both the $D$ and $L$ isomers of polyglutamate efficiently induced proteinase production. Poly-L-lysine also induced proteinase, but poly-D-lysine caused cell lysis. These results suggest that the sensor for proteinase production is not highly stereoselective and does not show a charge preference. Interestingly, polyglycine did not induce proteinase production, suggesting that the sensor may require interaction with side-chains of amino acid residues in proteins. Neither charged (heparin and dextran sulphate) nor neutral (dextran) non-protein polymers induced proteinase production. These results indicate that the sensory apparatus involved in induction of proteinase production must interact with both the main- and side-chains of protein molecules; however, the stereochemistry about the $\alpha$-carbon atom is not critically important. This contrasts with the requirement for $\mathrm{L}$ stereochemistry in the transport of peptides into Candida 
Table 3. Induction of secreted proteinase by peptides of defined length and sequence

Cells were grown in NL-YNB/glucose and amino acid supplements in the presence of peptide $\left(0.2 \mathrm{mg} \mathrm{ml}^{-1}\right)$. Proteinase activity was monitored in culture supernatants during growth, and peak activities were detected using the fluorogenic peptide substrate.

\begin{tabular}{|c|c|c|c|}
\hline Peptide & $\begin{array}{l}\text { No. of amino } \\
\text { acid residues }\end{array}$ & $\begin{array}{l}\text { Proteinase production } \\
\qquad\left(\mu \mathrm{g} \mathrm{ml}^{-1}\right)^{*}\end{array}$ & Peptide sequence \\
\hline Lys-Val & 2 & ND & KV \\
\hline Arg-Gly & 2 & ND & RG \\
\hline Laminin fragment & 5 & ND & YIGSR \\
\hline$\left[\mathrm{Met}^{5}\right]$ Enkephalin & 5 & ND & YGGFM \\
\hline Cholecystokinin fragment & 6 & ND & MGWMDF \\
\hline$\beta$-Lipotropin fragment & 7 & ND & KKDSGPY \\
\hline Cholecystokinin fragment & 7 & ND & YMGWMDF \\
\hline Angiotensin III & 7 & 0.42 & RVYIHPF \\
\hline Bradykinin fragment & 7 & ND & RPPGFSP \\
\hline$\left[\mathrm{Met}^{5}\right]$ Enkephalin-RGL & 8 & ND & YGGFMRGL \\
\hline Angiotensin II & 8 & 0.91 & DRVYIHPF \\
\hline Neurotensin fragment & 8 & 0.043 & ELYENKPR \\
\hline Bradykinin & 9 & ND & RPPGFSPFR \\
\hline Angiotensin I & 10 & $1 \cdot 50$ & DRVYIHPFHL \\
\hline Neurotensin fragment & 11 & 0.32 & ELYENKPRRPY \\
\hline Neurotensin & 13 & 0.76 & ELYENKPRRPYIL \\
\hline
\end{tabular}

${ }^{*}$ ND, Proteinase activity below the limit of detection $\left(<0.0014 \mu \mathrm{g} \mathrm{m}^{-1} ;<0.03 \%\right.$ of control).

albicans (Milewski et al., 1988). Furthermore, the induction of proteinase by poly-D-glutamate is strong evidence that neither small peptides, nor transport of small peptides, is required for proteinase induction, because poly-D-glutamate should not be a substrate for proteinase, nor would poly-D-glutamate oligopeptides be substrates for peptide transport.

\section{Survey of proteinase induction by peptides}

The minimal size required for induction of proteinase production was examined using a panel of 18 peptides ranging in length from 2 to 13 residues. Generally peptides 8 or more residues in length induced proteinase production while peptides of 7 or fewer residues did not (Table 3). Exceptions to this general rule include [Met ${ }^{5}$ ]enkephalin-Lys-Gly-Leu and bradykinin, 7- and 9mer peptides which did not induce, as well as angiotensin III, a 7-mer which did induce proteinase.

While this panel of peptides is not exhaustive, a few trends are evident from the composition and sequences of inducing and non-inducing peptides. All peptides examined which induced proteinase production contained the dipeptide sequence (His/Lys)-Pro and lacked Gly residues. Two preferred peptide cleavage sites for Candida proteinase are His-Thr (Capobianco et al., 1992), and Lys-Thr (S. Kadam, personal communication), indicating the preference for a basic residue in the P1 site. At present the relationship between these two pieces of data is unknown. All non-inducing peptides, larger than dipeptides, contained at least one Gly residue and lacked the dipeptide (His/Lys)-Pro motif. Since homopolymers of glutamate and lysine induced proteinase production the (His/Lys)-Pro motif is not strictly required for induction of proteinase production. However, the observation that the polyglycine homopolymer and all glycine-containing peptides did not induce proteinase production suggests that the sensory mechanism may detect side-chains at each residue along a specific length of the inducing peptide. Exceptions to these trends may be expected for peptides involved in pathogenesis or host defence. Such peptides, although larger than generally needed to elicit proteinase production, may not be recognized by the signalling system involved in induction of proteinase production. For example, the bradykinin 9-mer peptide, which was unable to elicit proteinase production, is the same peptide as released during activation of the kallikreinkinin system, thus causing increased vascular permeability (Kaminishi et al., 1990; Cutler, 1991). Cutler (1991) suggested that bradykinin-mediated activation of the kallikrein-kinin system may lead to the inflammatory reactions associated with the presence of C. albicans. Interestingly, Kaminishi et al. (1990) reported that Candida proteinase can activate the kallikrein-kinin system. Thus it might be beneficial to the host if a peptide associated with activation of the inflammatory response were unable to induce production of proteinase. 


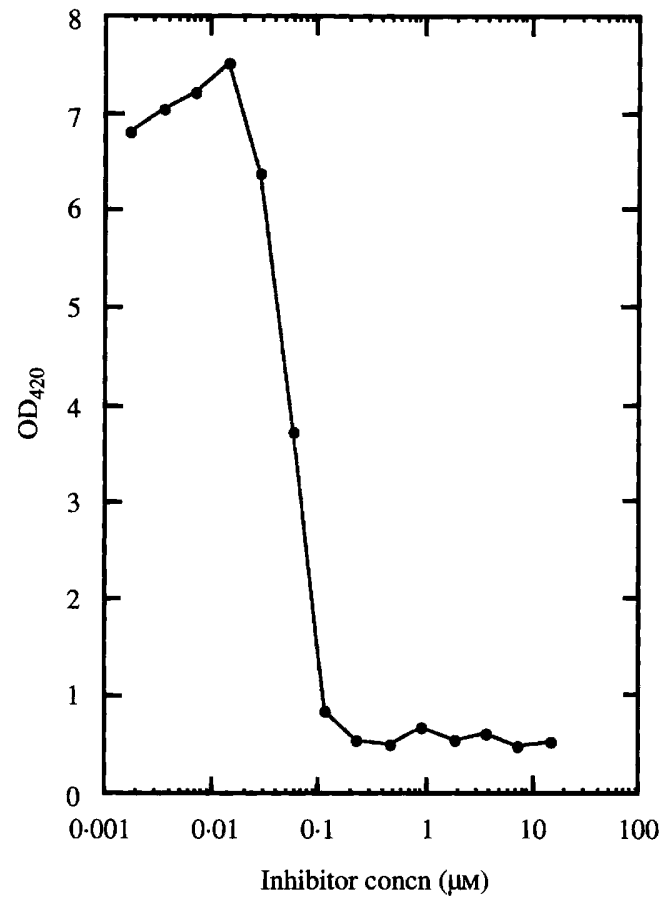

Fig. 3. Inhibition of growth of C. albicans strain ATCC 10261 on BSA by proteinase inhibitor A-70450. Nitrogen-starved cells were inoculated into $\mathrm{YNB} /$ glucose containing $0.025 \mathrm{mg}\left(\mathrm{NH}_{4}\right)_{2} \mathrm{SO}_{4} \mathrm{ml}^{-1}, 2.0 \mathrm{mg}$ BSA ml-1, and various concentrations of proteinase inhibitor. Growth was monitored at $420 \mathrm{~nm}$ after $18 \mathrm{~h}$.

\section{Proteinase production in presence of potent inhibitor of proteinase activity}

Previous reports have clearly established that the presence of exogenous protein leads to induction of proteinase. We have shown that peptides of sufficient size can also induce. However, from these data it is not clear whether fully intact protein can act as an efficient inducer of proteinase production. It is possible that only peptide fragments generated by a low basal level of constitutively produced proteinase act as inducer while full-length protein does not. We assessed the production of proteinase in medium containing inducer (BSA) plus the fast-tight binding proteinase inhibitor, A-70450 $\left(\mathrm{IC}_{50}=1.3 \mathrm{nM}\right.$, apparent $K_{\mathrm{i}}=0.17 \mathrm{nM}$; Capobianco et al., 1992), in order to answer this question. Since formation of proteolytic fragments would be blocked under these conditions, production of proteinase should not occur if peptide fragments are required for induction. Addition of inhibitor effectively blocked proteolysis in culture, since it completely inhibited cell growth on BSA as a sole nitrogen source (Fig. 3). Consistent with the fact that A-70450 is a tight-binding inhibitor (Capobianco $e t$ al., 1992) and should thus bind near-stoichiometrically with proteinase, the minimal growth inhibitory concentration of the inhibitor $(0 \cdot 1-0 \cdot 2 \mu \mathrm{M})$ was very close to the maximal molar concentration of proteinase produced $\left(0.14 \mu \mathrm{M}\right.$, based on an $M_{\mathrm{r}}$ of about 40000$)$. Since proteinase activity could not be assayed in cultures grown in the presence of A-70450, the amount of proteinase antigen production was measured by immunoblotting. Western blots of protein present in the culture supernatants were probed with anti-proteinase antiserum (Fig. 4). Addition of BSA without inhibitor resulted in production of proteinase activity as well as a large amount of proteinase antigen. Addition of inhibitor alone, in the absence of BSA, did not result in proteinase antigen production. The presence of proteinase inhibitor also did not inhibit growth when ammonium sulphate or amino acids were the low-molecular-mass nitrogen sources. Lower, but clearly detectable levels of proteinase antigen were detected in culture supernatants containing BSA plus the proteinase inhibitor, indicating that fully intact protein can induce proteinase production. However, peptides do seem to contribute to high-level induction of proteinase production, inasmuch as maximal production of proteinase antigen was observed in the absence of A-70450. Perhaps the degradation of BSA yields peptide sequences not exposed on intact BSA, sequences that are more potent and effective inducers of proteinase.

The fact that intact protein can induce proteinase may be relevant to the infectious process. Attachment of Candida to host cells and tissues should put a putative receptor in contact with intact host protein. Subsequent induction of proteinase could thus assist in the attachment and invasion process. Proteinase is produced in vivo (MacDonald \& Odds, 1980; Ruchel et al., 1983; De Bernardis et al., 1990), and in vitro when Candida comes into contact with host cells or tissue (Ruchel et al., 1986; Borg \& Ruchel, 1988, 1990).

\section{General conclusions}

We have developed a chemically-defined synthetic growth medium in which induction of the $C$. albicans secreted aspartyl proteinase can be determined (i) under conditions where previously nitrogen-starved cells deplete $\left(\mathrm{NH}_{4}\right)_{2} \mathrm{SO}_{4}$ while they are adapting to a protein nitrogen source, and (ii) with compounds that are not necessarily adequate nitrogen sources for cell growth. Studies with peptide homopolymers suggest that proteinase induction occurs via a sensory mechanism which requires both side- and main-chain interactions with the inducing polypeptide. Evaluation of a panel of peptides of defined size and sequence indicates that proteinase production is generally induced by peptides of 8 or more residues in length. Preliminary evidence suggests some sequence specificity involving a preference for a (His/Lys)-Pro motif in inducing peptides while peptides 


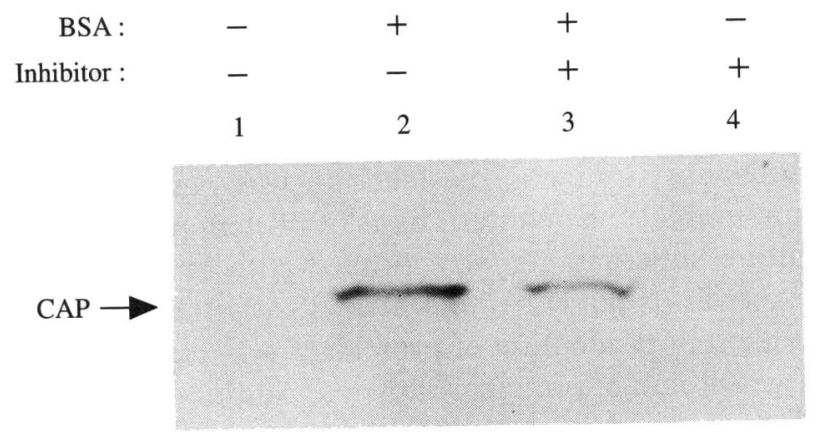

Fig. 4. Effect of proteinase inhibitor A-70450 on BSA induction of proteinase production. Nitrogen-starved $C$. albicans strain ATCC 10261 cells were inoculated into $\mathrm{YNB} /$ glucose containing $0.025 \mathrm{mg}\left(\mathrm{NH}_{4}\right)_{2} \mathrm{SO}_{4} \mathrm{ml}^{-1}$, amino acid supplements, $2.0 \mathrm{mg} \mathrm{BSA} \mathrm{ml}^{-1}$ and proteinase inhibitor, as indicated. Proteinase inhibitor was added to a final concentration of $0.5 \mu \mathrm{M}$ and samples were harvested for analysis after $9 \mathrm{~h}$ growth, which is near the peak for maximum proteinase production (see Fig. 2). Concentrated supernatant proteins were electrophoresed and transferred to nitrocellulose. Western blots were probed with antisera to the secreted aspartyl proteinase. CAP, C. albicans proteinase.

containing glycine residues apparently are unable to elicit proteinase production.

The existence of a mechanism which detects extracellular protein and signals proteinase induction is supported by the fact that (i) although Candida possesses multiple peptide transport systems which are repressed by ammonium ion, and induced by peptides (Payne et al., 1991), the size of peptides which induce proteinase production is greater than the size of peptide known to be transported by Candida peptide permeases (Milewski et al., 1988); (ii) poly-D-glutamate is an inducer, but not a substrate for proteinase, nor are D-peptides substrates for peptide transport (Milewski et al., 1988; Shallow et al., 1991), and (iii) significant induction of proteinase by BSA was observed in the presence of the tight-binding inhibitor A-70450. Furthermore, the yeast Saccharomyces cerevisiae contains G-protein-linked receptors for the peptide pheromone $\alpha$-factor, a peptide of 13 amino acids (Raths et al., 1988), demonstrating that peptides can initiate signal transduction in fungal cells. C. albicans also contains a homologous G-protein $\alpha$-subunit that functions in Saccharomyces (Sadhu et al., 1992), indicating that Candida may also possess the components of a functional signal transduction system. The possibility of proteinase induction following fluid-phase or receptor-mediated endocytosis can be excluded for peptides, since peptide permease mutants no longer accumulate, nor grow on, peptides (McCarthy et al., 1985; Payne \& Shallow, 1985; Payne, 1986; Milewski et $a l ., 1988)$ Fluid-phase or receptor-mediated endocytosis of protein, followed by transmission of the induction signal, can not, however, be excluded.

Recently the genes for secreted aspartyl proteinase from various Candida strains and species have been cloned and sequenced (Hube et al., 1991; Togni et al., 1991; Ganesan et al., 1991; Morrow et al., 1992; Wright et al., 1992). It now appears that a family of related aspartyl proteinase genes may exist in Candida, which raises the question as to how the various genes are regulated in vitro and in vivo, and what each of their roles may be in the infectious process. It may be that an ancestral gene used primarily for nutritional purposes duplicated and evolved specific functions related to pathogenesis. The expression, regulation, and function of this gene family both in vivo and in vitro is amenable to study, now that specific gene probes are available.

\section{References}

Ausubel, F. M., Brent, R., Kingston, R. E., Moore, D. D., Seidman, J. G., SMith, J. A. \& STRUHL, K. (1990). Saccharomyces cerevisiae. Current Protocols in Molecular Biology 2, 13.1.3.

BANERJEe, A., GANESAN, K. \& DATTA, A. (1991). Induction of secretory acid proteinase in Candida albicans. Journal of General Microbiology 137, 2455-2461.

BasRaI, M. M., NAIDER, F. \& BeckeR, J. M. (1990). Internalization of lucifer yellow in Candida albicans by fluid phase endocytosis. Journal of General Microbiology 136, 1059-1065.

BORG, M. \& RuCHEL, R. (1988). Expression of extracellular acid proteinase by proteolytic Candida during experimental infection of oral mucosa. Infection and Immunity 56, 626-631.

BORG, M. \& RUCHEL, R. (1990). Demonstration of fungal proteinase during phagocytosis of Candida albicans and Candida tropicalis. Journal of Medical and Veterinary Mycology 28, 3-14.

Capobianco, J. O., Lerner, G. G. \& Goldman, R. C. (1992). Application of a fluorogenic substrate in the assay of proteolytic activity and in the discovery of a potent inhibitor of Candida albicans aspartic proteinase. Analytical Biochemistry 203, 96-102.

Crandall, M. \& Edwards, J. E. (1987). Segregation of proteinasenegative mutants from heterozygous Candida albicans. Journal of General Microbiology 133, 2817-2824.

Cutler, J. E. (1991). Putative virulence factors of Candida albicans. Annual Review of Microbiology 45, 187-218.

De Bernardis, F., Agatensi, L., Ross, I. K., Emerson, G. W., LoRenZINI, R., Sullivan, P. A. \& CAssone, A. (1990). Evidence for a role for secreted aspartyl proteinase of Candida albicans in vulvovaginal candidiasis. Journal of Infectious Diseases 161, 1276-1283.

Douglas, L. J. (1988). Candida proteinases and candidosis. CRC Critical Reviews in Microbiology 8, 121-129.

Ganesan, K., BanerJeE, A. \& DatTa, A. (1991). Molecular cloning of the secretory acid proteinase gene from Candida albicans and its use as a species-specific probe. Infection and Immunity 59, 2972-2977.

GhanNoum, M. \& ABU ElteEN, K. (1986). Correlative relationship between proteinase production, adherence and pathogenicity of various strains of Candida albicans. Journal of General Microbiology 129, 431-438.

Hattori, M., Yoshiura, K., Negi, M. \& Ogawa, H. (1984). Keratinolytic proteinase produced by Candida albicans. Sabouraudia 22, 175-183.

Homma, M., Kanbe, T., Chibana, H. \& Tanaka, K. (1992). Detection of intracellular forms of secretory aspartic proteinase in Candida albicans. Journal of General Microbiology 138, 627-633.

Hube, B., Turver, C. J., Odds, F. C., Eiffert, H., Boulnois, G. J., KOCHEL, H. \& RUCHEL, R. (1991). Sequence of the Candida albicans gene encoding the secretory aspartate proteinase. Journal of Medical and Veterinary Mycology 29, 129-132.

Island, M. D., NAIDER, F. \& Becker, J. M. (1987). Regulation of dipeptide transport in Saccharomyces cerevisiae by micromolar amino acid concentrations. Journal of Bacteriology 169, 2132-2136. 
Kaminishi, H., Hagihara, Y., HaYAShI, S. \& CHO, T. (1986). Isolation and characteristics of collagenolytic enzyme produced by Candida albicans. Infection and Immunity 53, 312-316.

Kaminishi, H., Hagihara, Y., Tanaka, M. \& Cho, T. (1988). Degradation of bovine achilles tendon collagen by Candida albicans proteinase. Journal of Medical and Veterinary Mycology 26, 315-318.

Kaminishi, H., Tanaka, M., Cho, T., Maeda, H. \& Hagihara, Y. (1990). Activation of the plasma kallikrein-kinin system by Candida albicans proteinase. Infection and Immunity 58, 2139-2143.

KondOH, Y., Shimizu, K. \& TANAKA, K. (1987). Proteinase production and pathogenicity of Candida albicans. II. Virulence for mice of $C$. albicans strains of different proteinase activity. Microbiology and Immunology 31, 1061-1069.

Kwon-Chung, K. J., Lehman, D., Good, C. \& MageE, P. T. (1985). Genetic evidence for role of extracellular proteinase in virulence of Candida albicans. Infection and Immunity 49, 571-575.

McCarthy, P. J., Nisbet, L. J., BoenM, J. C. \& Kingsbury, W. D. (1985). Multiplicity of peptide permeases in Candida albicans: evidence from novel chromogenic peptides. Journal of Bacteriology 162, 1024-1029.

MACDONALD, F. (1984). Secretion of inducible proteinase by pathogenic Candida species. Journal of Medical and Veterinary Mycology 22, 79-82.

MACDonald, F. \& ODDS, F. C. (1980). Inducible proteinase of Candida albicans in diagnostic serology and the pathogenesis of systemic candidosis. Journal of Medical Microbiology 13, 423-435.

MACDONALD, F. \& OdDS, F. C. (1983). Virulence for mice of a proteinase-secreting strain of Candida albicans and a proteinasedeficient mutant. Journal of General Microbiology 129, 431-438.

MilewSKI, S., ANDRUSKIEWICZ, R. \& BorowsKi, E. (1988). Substrate specificity of peptide transport in Candida albicans. FEMS Microbiology Letters 50, 73-78.

Morrow, B., Srikantha, T. \& Soll, D. R. (1992). Transcription of the gene for a pepsinogen, $P E P 1$, is regulated by white-opaque switching in Candida albicans. Molecular and Cellular Biology 12, 2997-3005.

NAIDER, F. \& BeCKER, J. M. (1988). Peptide transport in Candida albicans: implications for the development of antifungal agents. Current Topics in Medical Microbiology 2, 170-198.

ODDs, F. C. (1985). Candida albicans proteinase as a virulence factor in the pathogenesis of Candida infections. Zentralblatt für Bakteriologie, Mikrobiologie und Hygiene (Abteilung I) 260, 539-542.

PAYNE, J. W. (1986). Drug delivery systems: optimising the structure of peptide carriers for synthetic antimicrobial drugs. Drugs Experimental Clinical Research 12, 585-594.

Payne, J. W. \& Shallow, D. A. (1985). Studies on drug targeting in the pathogenic fungus Candida albicans: peptide transport mutants resistant to polyoxins, nikkomycins and bacilysin. FEMS Microbiology Letters 28, 55-65.

Payne, J. W., Barrett-Bee, K. J. \& Shallow, D. A. (1991). Peptide substrates rapidly modulate expression of dipeptide and oligopeptide permease in Candida albicans. FEMS Microbiology Letters 79, $15-20$.

Raths, S. K., NaIder, F. \& Becker, J. M. (1988). Peptide analogs compete with the binding of alpha-factor to its receptor in Saccharomyces cerevisiae. Journal of Biological Chemistry 263, 17333-17341.

RAY, T. L. \& PAYNE, C. D. (1990). Comparative production and rapid purification of Candida acid proteinase from protein-supplemented cultures. Infection and Immunity 58, 508-514.

Remold, H., Fasold, H. \& Staib, F. (1968). Purification and characterization of a proteolytic enzyme from Candida albicans. Biochimica et Biophysica Acta 167, 399-406.

Ross, I. K., DeBernardis, F., Emerson, G. W., Cassone, A. \& Sullivan, P. A. (1990). The secreted aspartate proteinase of Candida albicans: physiology of secretion and virulence of a proteinasedeficient mutant. Journal of General Microbiology 136, 687-694.

RUCHEL, R. (1981). Properties of a purified proteinase from the yeast Candida albicans. Biochimica et Biophysica Acta 659, 99-113.

RuCHEL, R. (1983). On the role of proteinases from Candida albicans in the pathogenesis of acronecrosis. Zentralblatt für Bakteriologie, Mikrobiologie und Hygiene (Abteilung I) 255, 524-537.

RUCHEL, R. (1986). Cleavage of immunoglobulins by pathogenic yeasts of the genus Candida. Microbiological Sciences 3, 316-319.

Ruchel, R., UhlemanN, K. \& Boning, B. (1983). Secretion of acid proteinases by different species of the genus Candida. Zentralblatt für Bakteriologie, Mikrobiologie und Hygiene (Abteilung I) 255, 537-548.

RuCHEL, R., BONING, B. \& BORG, M. (1986). Characterization of a secretory proteinase of Candida parapsilosis and evidence for the absence of the enzyme during infection in vitro. Infection and Immunity 53, 411-419.

RuChel, R., ZimmermanN, F., Boning-STUtZer, B. \& Helmchen, U. (1991). Candidiasis visualized by proteinase-directed immunofluorescence. Virchows Archiv A, Pathological Anatomy and Histopathology 419, 199-202.

Sadhu, C., Hoekstra, D., McEachern, M. J., Reed, S. I. \& Hicks, J. B. (1992). A G-protein $\alpha$ subunit from asexual Candida albicans functions in the mating signal transduction pathway of Saccharomyces cerevisiae and is regulated by the a1- $\alpha 2$ repressor. Molecular and Cellular Biology 12, 1977-1985.

Shallow, D. A., Barrett-Bee, K. J. \& Payne, J. W. (1991). Evaluation of the dipeptide and oligopeptide permeases of Candida albicans as uptake routes for synthetic anticandidal agents. FEMS Microbiology Letters 79, 9-14.

STAIB, F. (1965). Serum-protein as nitrogen source for yeast-like fungi. Journal of Medical and Veterinary Mycology 4, 187-193.

Togni, G., SAnglard, D., Falchetto, R. \& Monod, M. (1991). Isolation and nucleotide sequence of the extracellular acid protease gene (ACP) from the yeast Candida tropicalis. FEBS Letters 286, 181-185.

Wright, R. J., Carne, A., Hieber, A. D., Lamont, I. L., Emerson, G. W. \& Sullivan, P. A. (1992). A second gene for a secreted aspartate proteinase in Candida albicans. Journal of Bacteriology 174, 7848-7853. 